University of Nebraska - Lincoln

DigitalCommons@University of Nebraska - Lincoln

Faculty Papers and Publications in Animal

Science

Animal Science Department

January 1982

\title{
OXIDATION RATES OF MAJOR FATTY ACIDS IN FASTING NEONATAL PIGS
}

\author{
R. D. Boyd \\ University of Nebraska-Lincoln \\ R. A. Britton \\ University of Nebraska-Lincoln \\ H. Knoche \\ University of Nebraska-Lincoln \\ B. D. Moser \\ University of Nebraska-Lincoln \\ E. R. Peo Jr. \\ University of Nebraska-Lincoln \\ See next page for additional authors
}

Follow this and additional works at: https://digitalcommons.unl.edu/animalscifacpub

Part of the Animal Sciences Commons

Boyd, R. D.; Britton, R. A.; Knoche, H.; Moser, B. D.; Peo, E. R. Jr.; and Johnson, R. K., "OXIDATION RATES OF MAJOR FATTY ACIDS IN FASTING NEONATAL PIGS" (1982). Faculty Papers and Publications in Animal Science. 24.

https://digitalcommons.unl.edu/animalscifacpub/24

This Article is brought to you for free and open access by the Animal Science Department at DigitalCommons@University of Nebraska - Lincoln. It has been accepted for inclusion in Faculty Papers and Publications in Animal Science by an authorized administrator of DigitalCommons@University of Nebraska - Lincoln. 


\section{Authors}

R. D. Boyd, R. A. Britton, H. Knoche, B. D. Moser, E. R. Peo Jr., and R. K. Johnson 


\title{
OXIDATION RATES OF MAJOR FATTY ACIDS IN FASTING NEONATAL PIGS ${ }^{1,2}$
}

\author{
R. D. Boyd ${ }^{3}$, R. A. Britton, H. Knoche, B. D. Moser, \\ E. R. Peo, Jr. ${ }^{4}$ and R. K. Johnson \\ University of Nebraska, Lincoln 68583
}

\begin{abstract}
Summary
Thirty-two pigs were used to compare the oxidation rates of uniformly labeled $\left(\mathrm{U}^{14} \mathrm{C}\right)$ palmitic (16:0), stearic $(18: 0)$, oleic $(18: 1)$ and linoleic (18:2) acids in fasting neonatal pigs. The pigs were allowed to nurse the sow for 24 to $48 \mathrm{~h}$ following birth. Subsequently, they were removed, an indwelling catheter was surgically placed in the external iliac vein and the pigs were fasted for $12 \mathrm{~h}$ to attain a postabsorptive state. The ${ }^{14} \mathrm{C}$ fatty acids were administered as a single infusion $(10 \mu \mathrm{Ci})$ via the catheter, and recovery of the label as expired ${ }^{14} \mathrm{CO}_{2}$ was determined at $45-\mathrm{min}$ intervals for a 6 -h period. Blood samples were taken following the infusion $(15,60,120,240$, $360 \mathrm{~min}$ ) to monitor activity maintained within the free fatty acid (FFA) fraction of the plasma pool. The oxidation rate of each fatty acid was corrected for the difference in dose dilution using a uniform factor based on plasma concentration of 18:1. The cumulative $6-\mathrm{h}{ }^{14} \mathrm{CO}_{2}$ recovery rates (percentage of dose) were 19.1, 6.6, 30.1 and $13.1 \%$ for $16: 0,18: 0,18: 1$ and $18: 2$, respectively. Oleic acid was oxidized at a more $(\mathrm{P}<.05)$ rapid rate than the other fatty acids. Palmitic acid and 18:2 were oxidized more rapidly than 18:0, although the difference between 18:0 and 18:2 was not significant. Plasma FFA pools differed with respect to the proportion of infused activity remaining at
\end{abstract}

\footnotetext{
${ }^{1}$ Published as Paper No. 6598, Journal Ser., Nebraska Agr. Exp. Sta.

${ }^{2}$ Depts. of Anim. Sci. and Agr. Biochem. The authors wish to express appreciation to the Fats and Proteins Research Foundation, Des Plaines, IL, for grant-in-aid support of this project.

${ }^{3}$ Present address: Dept. of Anim. Sci., Cornell Univ., lthaca, NY.

"Person to whom reprint requests should be directed.
}

various times after administration. At 60 and $120 \mathrm{~min}$ postinfusion, the greatest $(\mathrm{P}<.05)$ proportion of activity was maintained in the 18:1 pool (11.9 and 6.6\%, respectively, vs 7.7 and $4.3 \%$ for $16: 0,6.9$ and $3.9 \%$ for $18: 2$ and 3.6 and $2.2 \%$ for 18:0). Palmitic acid and 18:2 had a greater $(\mathrm{P}<.05)$ level of activity in the plasma FFA pool at $60 \mathrm{~min}$ than did 18:0. This same pattern was observed through $2 \mathrm{~h}$, but by $240 \mathrm{~min}$ postinfusion, the proportion of activity remaining in each of the plasma pools was similar. Rate of oxidation appeared to correspond with plasma concentration and proportion of activity remaining in the plasma FFA pool.

(Key Words: Neonatal Pig, Free Fatty Acids, Oleic, Palmitic, Linoleic, Stearic.)

\section{Introduction}

Various aspects of energy metabolism in newborn pigs have been investigated because it is apparent that susceptibility to hypoglycemia development is a major cause of death. An important consideration is the contribution that free fatty acids (FFA) make to the energy status of neonatal pigs which are unable to compete effectively with littermates nursing the dam. Certain fatty acids may be more beneficial by contributing more energy and thus sparing glucose utilization and enhancing survivial. Knowledge about differences in oxidation rates of individual fatty acids is important, because the pattern of fatty acids in the lipid fraction of the fetal pig, colostrum and milk can be altered by dietary lipid source consumed by the dam (Seerley and Poole, 1974; Seerley et al., 1978a,b).

Differences in oxidation rates of fatty acids have been reported in a number of species (Goransson and Olivecrona, 1965; Miller, 1970; Mathias et al., 1973; Lindsay, 1975), however, little research has been conducted with the 95 
oxidation rates of four fatty acids in neonatal pigs. Accurate comparison among the fatty acids studied was precluded by different rates of dilution of the radioactive fatty acids in respective plasma FFA pools (Miller, 1970). Seerley and Poole (1974) determined, by comparative slaughter, that there are differences among fatty acids with respect to the degree of utilization for energy by fasting neonatal pigs. It was not possible to determine from their data, however, if the utilization rate of several of the major fatty acids differed during the initial stages of fasting, because the pigs were subjected to a prolonged fast $(72 \mathrm{~h})$.

This experiment was conducted to determine the rate of oxidation of certain fatty acids by neonatal pigs during the initial stages of fasting. The fatty acids chosen represent approximately $80 \%$ of the predominant fatty acids in plasma and adipose tissue of piglets (Lodge et al., 1978).

\section{Experimental Procedure}

Thirty-two pigs, eight from each of four litters, were allotted within sex and litter to one of four fatty acid infusion treatments. Approximately $24 \mathrm{~h}$ after birth, four male pigs were removed from the litter and fasted for $12 \mathrm{~h}$ in order to attain a postabsorptive state. Approximately $48 \mathrm{~h}$ after birth, four female pigs were separated from the dam and treated similarly. Early in the fasting phase, an indwelling cathe$\operatorname{ter}^{5}$ (id $.71 \mathrm{~mm}$, od $1.17 \mathrm{~mm}$ ) was surgically placed in the external iliac vein (approximately $60 \mathrm{~mm}$ ). General anesthesia was initiated with 2-bromo-2 chloro-1,1,1-trifluoroethane (halothane $)^{6}$ and maintained with nitrous oxide and oxygen. Local anesthesia was effected with lidocaine hydrochloride ${ }^{7}$. The catheter was maintained with a saline solution without heparin.

At the end of the 12-h fast, pigs were

\footnotetext{
${ }^{5}$ Becton-Dickinson, Rutherford, NJ.

${ }^{6}$ Ayerst Laboratory, Inc., New York, NY. MA.

${ }^{7}$ Astra Pharmaceutical Products, Inc., Worcester,

${ }^{8}$ New England Nuclear, Boston, MA.

${ }^{9}$ Amersham Corp., Arlington Heights, IL.

${ }^{10}$ United States Biochemical Corp., Cleveland, $\mathrm{OH}$.

${ }^{11}$ Model 3385, Packard Instrument Co., Inc., Downers Grove, IL.
}

secured in comfort slings and fitted with a face mask in order to trap the carbon dioxide. Once their feet were suspended and an infrared heat lamp was turned on, the animals usually slept through the 6-h experiment. The pigs were infused with approximately $1 \mathrm{ml}$ of the appropriate individual aqueous $\left(\mathrm{U}-{ }^{14} \mathrm{C}\right.$ ) fatty acid solution containing $10 \mu \mathrm{Ci}$ of radioactivity. After infusion, the catheter was immediately flushed with 30 volumes of saline $(1.5 \mathrm{ml})$.

Uniformly labeled palmitic ${ }^{8} \quad(16: 0,613$ $\mathrm{mCi} / \mathrm{mmol})$, oleic ${ }^{8}(18: 1,789 \mathrm{mCi} / \mathrm{mmol})$, linoleic $^{8}(18: 2,854 \mathrm{mCi} / \mathrm{mmol})$ and stearic acids $^{9}(18: 0,200 \mathrm{mCi} / \mathrm{mmol})$ were purchased from commercial sources and utilized without further purification. The carrier solvents were evaporated under $\mathrm{N}_{2}$ at $37 \mathrm{C}$, and the fatty acids were then dissolved in absolute ethanol. For infusions, fatty acids were converted to potassium salts. A slightly greater than equimolar quantity of potassium hydroxide was added to the ethanol system and maintained at $37 \mathrm{C}$ for 30 to $40 \mathrm{~min}$ with periodic mixing. The fatty acid species was then complexed with fatty acid poor bovine serum albumin ${ }^{10}(1 \mathrm{~mol}$ bovine serum albumin: $5 \mathrm{~mol}$ fatty acid). The mixture was diluted with an appropriate volume of saline solution and the specific activity of the mixture determined with a liquid scintillation spectrophotometer ${ }^{11}$. The vials were then flushed with $\mathrm{N}_{2}$ and stored $(-10 \mathrm{C})$ until infused within 7 to $10 \mathrm{~d}$.

The expired carbon dioxide was collected by drawing the effluent gas through a series of three flasks, each containing $100 \mathrm{ml}$ of $1 \mathrm{~N}$ $\mathrm{NaOH}$, the contents of the flasks were changed at $45-\mathrm{min}$ intervals through a $360-\mathrm{min}$ period, and duplicate $5-\mathrm{ml}$ aliquots were taken, mixed with $10 \mathrm{ml}$ of scintillation solution (Aquasol) ${ }^{8}$ and radioactivity determined. The ${ }^{14} \mathrm{CO}_{2}$ collection procedure was verified for each of the four stations by placing $2 \mu \mathrm{Ci}$ of ${ }^{14} \mathrm{C}$ sodium bicarbonate $\left(\mathrm{NaH}^{14} \mathrm{CO}_{3}\right)$ in a flask and then adding $10 \mathrm{ml}$ of $1 \mathrm{~N} \mathrm{H}_{2} \mathrm{SO}_{4}$. The activity recovered during a series of 3 -h collection periods demonstrated that each station was collecting with equal efficiency.

Blood samples $(2 \mathrm{ml})$ were withdrawn from the catheter at predetermined intervals after infusion $(15,60,120,240$ and $360 \mathrm{~min})$ so that the specific activity of the infused fatty acid relative to the plasma FFA pool could be monitored. After each sampling, the catheter 
TABLE 1. RATE OF FATTY ACID OXIDATION IN FASTING NEONATAL PIGS GIVEN A SINGLE DOSE OF (U- $\left.{ }^{14} \mathrm{C}\right)$ PALMITIC, STEARIC, OLEIC OR LINOLEIC ACID

\begin{tabular}{|c|c|c|c|c|c|}
\hline \multirow[b]{2}{*}{ I tem } & \multicolumn{4}{|c|}{ Fatty acid } & \multirow[b]{2}{*}{$\mathrm{SE}^{\mathrm{a}}$} \\
\hline & $16: 0$ & $18: 0$ & $18: 1$ & $18: 2$ & \\
\hline No. pigs & 8 & 8 & 8 & 8 & \\
\hline Mean wt, $g$ & 1,433 & 1,447 & 1,371 & 1,474 & 75 \\
\hline \multicolumn{6}{|l|}{ Recovery of ${ }^{14} \mathrm{CO}_{2}$} \\
\hline \multicolumn{6}{|l|}{ Min } \\
\hline 45 & 5.55 & 2.74 & 6.68 & 6.63 & \\
\hline 90 & 5.71 & 4.24 & 6.84 & 6.94 & \\
\hline 135 & 3.83 & 3.46 & 4.63 & 4.73 & \\
\hline 180 & 3.09 & 2.65 & 3.94 & 3.59 & \\
\hline 225 & 2.37 & 1.77 & 2.96 & 2.96 & \\
\hline 270 & 1.90 & 1.53 & 2.13 & 2.24 & \\
\hline 315 & 1.60 & 1.25 & 1.70 & 1.59 & \\
\hline 360 & 1.36 & 1.03 & 1.24 & 1.54 & \\
\hline Cumulative recovery & $25.41 \mathrm{y}$ & $18.67^{z}$ & $30.12^{x}$ & $30: 22^{x}$ & 1.25 \\
\hline
\end{tabular}

was flushed with 12 volumes of saline $(.6 \mathrm{ml})$. The samples were placed in heparinized tubes and chilled on ice until centrifuged. After centrifugation, the plasma was frozen $(-10 \mathrm{C})$ until.analyzed.

FFA were extracted from an aliquot of plasma by the procedure of Carruthers and Young (1973), and any remaining lipid components were removed by thin layer chromatography (Huang and Kuksis, 1967). Part of the extract was analyzed for radioactivity, while the remainder was analyzed for the concentration of the fatty acids under study. The proportion of activity associated with the plasma FFA pool was calculated for each of the specified intervals postinfusion using an estimated plasma volume. This estimate was derived using the relationship between body weight and plasma volume ( $71 \mathrm{ml} / \mathrm{kg}$ body weight) determined by Talbot and Swenson (1970).

\footnotetext{
${ }^{12}$ Model 5840, Hewlett-Packard, Avondale, PA.

${ }^{13}$ Supelco Tech. Bull. No. 721C, Supelco, Inc., Bellefonte, PA.

${ }^{14}$ Applied Sciences Lab, Inc., State College, PA.
}

Data obtained from liquid scintillation counting for both plasma and sodium hydroxide samples were corrected for quench with the aid of an internal standard $\left({ }^{14} \mathrm{C} \text {-toluene }\right)^{8}$. Counting efficiency was $82 \%$ for the infusion mixture and plasma FFA extract and $74 \%$ for the $\mathrm{NaOH}$ medium. Individual plasma FFA were quantified by gas-liquid chromatography with an auto-injection chromatograph ${ }^{12}$. Heptadecanoic acid (17:0) was included as an internal standard. Methyl esters were prepared according to procedures outlined by Supelco, Inc. ${ }^{13}$, with trifluoride methanol ${ }^{14}$ used as the methylating agent. The methyl esters were partitioned on a column packed with SP- $2330^{14}$ after conditioning overnight at $210 \mathrm{C}$. Separation was accomplished by temperature programming with an initial column temperature of $165 \mathrm{C}$ for $4 \mathrm{~min}$. The temperature ramp was set at 5 $\mathrm{C} / \mathrm{min}$ up to a final temperature of $210 \mathrm{C}$. Temperature of the injection port was $235 \mathrm{C}$, while the flame ionization detector temperature was maintained at $275 \mathrm{C} . \mathrm{N}_{2}$ flow rate was maintained at $20 \mathrm{ml} / \mathrm{min}$.

Six-hour ${ }^{14} \mathrm{CO}_{2}$ recoveries (i.e., oxidation rates) were computed relative to a uniform initial dilution using the following formula: 


$$
\begin{aligned}
& \text { Corrected cumulative }{ }^{14} \mathrm{CO}_{2} \text { recovery }= \\
& {\left[\begin{array}{c}
\text { Uncorrected } \\
\text { cumulative } \\
\text { recovery }
\end{array}\right]\left[\frac{\text { Plasma } \mathrm{FFA}_{\mathrm{i}}, \mu \mathrm{g} / \mathrm{ml}}{\text { Plasma } 18: 1, \mu \mathrm{g} / \mathrm{ml}}\right] .}
\end{aligned}
$$

The standardization was based on the concentration of $18: 1$ because the $10 \mu \mathrm{Ci}$ dose of $18: 1$ was diluted to the greatest extent in the plasma pool. All data were analyzed statistically by analysis of variance according to the Statistical Analysis System (Barr et al., 1976). Paired mean comparisons were made among the six possible treatment combinations by the StudentNewman-Keul's test (Steel and Torrie, 1960).

\section{Results and Discussion}

The rate of ${ }^{14} \mathrm{CO}_{2}$ recovery reported in table 1 is expressed as the proportion of infused dose recovered per $45-\mathrm{min}$ interval, and includes a cumulative mean for the 6-h period. The rate of recovery appeared to be maximized during the 45 to $90 \mathrm{~min}$ period and steadily declined thereafter. Cumulative 6 -h recoveries were 25.4 , $18.7,30.1$ and $30.2 \%$ for $16: 0,18: 0,18: 1$ and $18: 2$, respectively. More $(\mathrm{P}<.05){ }^{14} \mathrm{CO}_{2}$ was recovered from 18:1 and 18:2 than from their saturated counterparts. Stearic acid yielded the least $(\mathrm{P}<.05){ }^{14} \mathrm{CO}_{2}$ and thus appeared to be the most poorly oxidized; the oxidation rate of 16:0 was intermediate.

A direct comparison of the oxidation rate would be misleading, however, unless differences in dilution of the $10 \mu \mathrm{Ci}$ dose in the plasma FFA pool were quantified and the results standardized. Therefore, concentrations of the individual FFA were determined in samples acquired $15 \mathrm{~min}$ postinfusion and used as a basis for correcting ${ }^{14} \mathrm{CO}_{2}$ activity data (table 2). Mean plasma concentrations were 38.2, 17.8, 50.4 and $21.9 \mu \mathrm{g} / \mathrm{ml}$ for $16: 0,18: 0,18: 1$ and 18:2, respectively. Oleic acid and 16:0 were present in greater $(P<.05)$ quantities than 18:2 or 18:0. Although not significantly different, the concentration of 18:1 appeared to be greater than that of 16:0. The relative proportion of plasma fatty acids correspond well with data presented by Lodge et al. (1978) for pigs that nursed 3 to $12 \mathrm{~h}$.

Fatty acid oxidation data, adjusted for differences in dilution of the radioactivity within the respective plasma FFA pools, are presented in table 2 . This resulted in recovery rates of $19.1,6.6,30.1$ and $13.1 \%$ for $16: 0$, 18:0, 18:1 and 18:2, respectively. A different ranking resulted with respect to the proportion of FFA oxidized. Oleic acid was still determined to be oxidized most $(\mathrm{P}<.05)$ rapidly; however, 18:2 was not oxidized more rapidly than 16:0, and in fact, the reverse may have been true. Palmitic acid was oxidized more rapidly $(P<.05)$ than 18:0, which was the most poorly oxidized of the four fatty acids studied.

Estimating the zero time specific activity of the plasma FFA pool from the intercept of a semilogarithmic plot is not an alternative means of determining dose dilution in single infusion experiments with FFA. Fredrickson and Gordon (1958) reported that a significant amount of the radioactivity was removed from circulation before mixing was complete because of rapid FFA turnover. It is known, for example, that as much as $30 \%$ of the FFA flux flowing through the liver is removed on a single passage (Steinberg and Khoo, 1977).

TABLE 2. PLASMA CONCENTRATIONS AND OXIDATION RATES OF PALMITIC,

\begin{tabular}{|c|c|c|c|c|c|}
\hline \multirow[b]{2}{*}{ I tem } & \multicolumn{4}{|c|}{ Fatty acid } & \multirow[b]{2}{*}{$\mathrm{SE}^{\mathrm{a}}$} \\
\hline & $16: 0$ & $18: 0$ & $18: 1$ & $18: 2$ & \\
\hline Plasma concentration, $\mu \mathrm{g} / \mathrm{ml}^{b}$ & $38.2^{x}$ & $17.8^{y}$ & $50.4^{x}$ & $21.9 \mathrm{y}$ & 4.4 \\
\hline $\begin{array}{l}\text { Cumulative }{ }^{14} \mathrm{CO}_{2} \text { recovery, } \% \\
\text { Uncorrected } \\
\text { Corrected }{ }^{\mathrm{C}}\end{array}$ & $\begin{array}{l}25.4 y \\
19.1 Y\end{array}$ & $\begin{array}{r}18.7^{z} \\
6.6^{z}\end{array}$ & $\begin{array}{l}30.1^{x} \\
30.1^{x}\end{array}$ & $\begin{array}{l}30.2^{\mathrm{x}} \\
13.1^{\mathrm{yz}}\end{array}$ & $\begin{array}{l}1.2 \\
2.2\end{array}$ \\
\hline
\end{tabular}
STEARIC, OLEIC AND LINOLEIC ACIDS IN FASTING NEONATAL PIGS

\footnotetext{
${ }^{a}$ Standard error of the mean.

${ }^{b}$ Determined on samples collected 15 min postinfusion.

${ }^{c}$ Cumulative 6-h means adjusted for differences in plasma concentration of the FFA species infused. See text. $x, y, z$ Means in the same row with different superscripts differ $(P<.05)$.
} 
The proportion of infused ${ }^{14} \mathrm{C}$ activity associated with the plasma FFA pool was determined for each FFA at 15, 60, 120, 240 and $360 \mathrm{~min}$ postinfusion (table 3 ). The data for the 15-, 60- and 120-min determinations demonstrate that the plasma FFA pools differed with respect to the degree of radioactivity maintained therein. The pattern appeared to be approximately the same for the $60-$ and $120-\mathrm{min}$ determinations, with the greatest $(P<.05)$ proportion of activity maintained in the $18: 1$ pool ( 11.9 and $6.6 \%$ vs 7.7 and $4.3 \%$ for $16: 0$, 6.9 and $3.9 \%$ for $18: 2$, and 3.6 and $2.2 \%$ for 18:0). Although the differences were not significant, the plasma pools of 16:0 and 18:2 had more activity than $18: 0$ at $120 \mathrm{~min}$. By $240 \mathrm{~min}$, the proportion of activity remaining in each of the plasma pools was similar.

The data demonstrate that the fatty acids differed with respect to the proportion of infused radioactivity partitioned to other lipid fractions and away from the oxidatively active plasma FFA pool. Dittmer and Hanahan (1959) reported that individual fatty acids are incorporated into various lipid fractions in different proportions. Miller et al. (1971) reported that serum phospholipids, diglyceride and cholesterol fractions in neonatal pigs contained the greatest proportion of radioactivity when 18:2 was administered compared to $18: 1$ and $16: 0$

The data support the hypothesis that lipid sources that contain a higher percentage of certain fatty acids may be more important in meeting energy needs and thus enhancing survival of neontatal pigs (Seerley and Poole, 1974). Of the four major fatty acids, 18:1 was the most rapidly oxidized. Palmitic acid and 18:2 were intermediate, while $18: 0$ was the most poorly oxidized fatty acid. The results are in agreement with those of Seerley and Poole (1974), who determined by comparative slaughter, that 18:1 was utilized most rapidly per unit time in newborn pigs fasted $72 \mathrm{~h}$. They estimated that $35 \%$ of the total grams utilized during fasting was provided by 18:1. Stearic acid was the most poorly utilized fatty acid, except for arachidonic acid, which appeared not to decrease with fasting. Palmitic acid and 18:2 contributed the same proportion of their initial content (approximately 55\%) when compared to $18: 1$, but they are present in the carcass in smaller quantities. Palmitic acid, however, is second in quantity only to $18: 1$. Palmitoleic acid was also well utilized during fasting $(72 \%)$ and is present in a sufficient amount to be considered a significant contributor to the energy status during fasting.

Using homogenates of liver, Wolfe et al.

TABLE 3. PROPORTION OF THE RADIOACTIVITY $\left({ }^{14} \mathrm{C}\right)$ REMAINING IN THE PLASMA FREE FATTY ACID POOL AFTER INFUSION

\begin{tabular}{|c|c|c|c|c|c|}
\hline \multirow[b]{2}{*}{ I tem } & \multicolumn{4}{|c|}{ Fatty acid } & \multirow[b]{2}{*}{$\mathrm{SE}^{\mathrm{a}}$} \\
\hline & $16: 0$ & $18: 0$ & $18: 1$ & $18: 2$ & \\
\hline $\begin{array}{l}\text { Body wt, } g \\
\text { Plasma volume, } \mathrm{ml}^{\mathrm{b}}\end{array}$ & $\begin{array}{r}1,433 \\
102\end{array}$ & $\begin{array}{r}1,447 \\
103\end{array}$ & $\begin{array}{r}1,371 \\
97\end{array}$ & $\begin{array}{r}1,474 \\
105\end{array}$ & $\begin{array}{l}75 \\
5.3\end{array}$ \\
\hline \multicolumn{6}{|l|}{ FFA poolc } \\
\hline $\begin{array}{l}\text { Min postinfusion } \\
15 \\
60 \\
120 \\
240 \\
360\end{array}$ & $\begin{array}{r}17.4 \mathrm{y} \\
7.7 \mathrm{y} \\
4.3 \mathrm{y} \\
2.3^{\mathrm{x}} \\
1.1^{\mathrm{x}}\end{array}$ & $\begin{array}{r}8.8^{z} \\
3.6^{z} \\
2.2 y \\
1.7^{x} \\
.8^{x}\end{array}$ & $\begin{array}{r}33.0^{x} \\
11.9^{x} \\
6.6^{x} \\
3.1^{x} \\
1.9^{x}\end{array}$ & $\begin{array}{c}25.4^{x y} \\
6.9^{y} \\
3.9 y \\
3.2^{x} \\
1.5^{x}\end{array}$ & $\begin{array}{r}2.8 \\
1.1 \\
.7 \\
.4 \\
.3\end{array}$ \\
\hline
\end{tabular}


(1978) determined that 16:0 was utilized by neonatal pigs at a faster rate than 18:0 or myristic acid. In addition, 16:0 oxidation was enhanced with age and paralleled increases in mitochondrial protein, which suggests an increased capacity to utilize fat as an energy substrate during early development.

The newborn pigs' ability to mobilize (and utilize) fatty acids in response to starvation (Swiatek et al., 1968; Bengtsson et al., 1969; Gentz et al., 1970; Boyd et al., 1981) must be considered in the context of low body fat storage at birth in combination with limited ability to oxidize this substrate initially (Mersmann and Phinney, 1973). The fetal pig does not have the high rates of liver lipognesis observed in other species (Mersmann et al., 1973). Fetal pig adipose tissue does not synthesize fatty acids to any extent, because very little depot fat exists. The low degree of liver fatty acid oxidative capacity may also be a major reason for reduced gluconeogenic capacity observed in the newborn (Kasser, 1979). Colostrum and milk appear to be the major routes for lipid acquisition by newborn pigs, suggesting that some nursing must occur for this substrate to contribute significantly to energy needs. Therefore, much research remains to be done in the area of fetal lipid metabolism.

\section{Literature Cited}

Barr, A. J., J. H. Goodnight, J. P. Sall and J. T. Helwig. 1976. A User's Guide to SAS 76. SAS Institute Inc., Raleigh, NC.

Bengtsson, G., J. Gentz, J. Hakkarainen, R. Hellstrom and B. Persson. 1969. Plasma levels of FFA, glycerol, $\beta$-hydroxybutyrate and blood glucose during the postnatal development of the pig. $J$. Nutr. 97:311.

Boyd, R. D., B. D. Moser, A. J. Lewis, E. R. Peo, Jr., R. K. Johnson and R. D. Nimmo. 1981. Effect of maternal dietary energy source on glucose homeostasis, liver glycogen and carcass lipid in the neonatal pig. J. Anim. Sci. 53:1316.

Carruthers, M. and D.A.B. Young. 1973. Free fatty acid estimation by a semi-automated fluorimetric method. Clin. Chim. Acta 49:341.

Dittmer, J. C. and D. J. Hanahan. 1959. Biochemistry of long chain fatty acids. II. Metabolic studies. J. Biol. Chem, 234:1983.

Fredrickson, D. S. and R. S. Gordon, Jr. 1958. The metabolism of albumin-bound $C^{14}$-labelled unesterified fatty acids in normal human subjects. J. Clin. Invest. 37:1504.

Gentz, J., G. Bengtsson, J. Hakkarainen, R. Hellstrom and B. Persson. 1970. Metabolic effects of starvation during neonatal period in the piglet. Amer. J. Physiol. 218:662.

Goransson, G. and T. Olivecrona. 1965. The metabolism of fatty acids in the rat. II. Oleic acid. Acta Physiol. Scand. 63:121.

Huang, T. C. and A. Kuksis. 1967. A comparative study of the lipids of chylomicron membrane and fat core and of the lymph serum of dogs. J. Lip. Res. $2: 443$.

Kasser, T. R. 1979. Effects of maternal fasting, diabetes and genetic obesity in neonatal survival and fetal development in pigs. M.S. Thesis. Pennsylvania State Univ., University Park.

Lindsay, D. B. 1975. Fatty acids as energy sources. Proc. Nutr. Soc. 34:241.

Lodge, G. A., N. K. Sarkar and J.K.G. Kramer. 1978. Fat deposition and fatty acid composition in the neonatal pig. J. Anim. Sci. 47:497.

Mathias, M. M., J. Dupont and D. H. Hwang. 1973. In vitro fatty acid oxidation rates in rat heart and liver. Life Sci. 13:257.

Mersmann, H. J. and G. Phinney. 1973 In vitro fatty acid oxidation in liver and heart from neonatal swine (sus domesticus). Comp. Biochem. Physiol. 44B : 219

Mersmann, H. J., G. Phinney, M. C. Sanguinetti and J. M. Houk. 1973. Lipogenic capacity of liver from perinatal swine (sus domesticus). Comp. Biochem. Physiol. 46B:493.

Miller, G. M. 1970. Fatty acid utilization in the young pig. Ph.D. Dissertation. Purdue Univ., Lafayette, IN.

Miller, G. M., J. H. Conrad, T. W. Keenan and W. R. Featherston. 1971. Fatty acid oxidation in young pigs. J. Nutr. 101:1343.

Seerley, R. W., F. M. Griffin and H. C. McCampbell. 1978a. Effect of sow's dietary energy source on sow's milk and piglet carcass composition. J. Anim. Sci. 46:1009.

Seerley, R. W., J. S. Maxwell and H. C. McCampbell. $1978 \mathrm{~b}$. A comparison of energy sources for sows and subsequent effect on piglets. J. Anim. Sci. 47:1114.

Seerley, R. W. and D. R. Poole. 1974. Effect of prolonged fasting on carcass composition and blood fatty acids and glucose of neonatal swine. J. Nutr. 104:210.

Steel, R.G.D. and J. H. Torrie. 1960. Principles and Procedures of Statistics. McGraw Hill Co., New York.

Steinberg, D. and J. C. Khoo. 1977. Hormone-sensitive lipase of adipose tissue. Fed. Proc. 36:1986.

Swiatek, K. R., D. M. Kipnis, G. Mason, K. L. Chao and M. Cornblath. 1968. Starvation hypoglycemia in newborn pigs. Amer. J. Physiol. 214: 400.

Talbot, R. B. and M. J. Swenson. 1970. Blood volume of pigs from birth through 6 weeks of age. Amer. J. Physiol. 218:1141.

Wolfe, R. G., C. V. Maxwell and E. C. Nelson. 1978. Effect of age and dietary fat level on fatty acid oxidation in the neonatal pig. J. Nutr. 108:1621. 